\title{
Nanotechnology and stem cells in vascular biology
}

\author{
Tomasz Jadczyk ${ }^{1,2, *}$, Guido Caluori1,3,*, Wojciech Wojakowski1 and Zdenek Starek 2,4 \\ 1Department of Cardiology and Structural Heart Diseases, Medical University of Silesia, Katowice, Poland \\ IInterventional Cardiac Electrophysiology Group, International Clinical Research Center, St. Anne's University Hospital Brno, Brno, Czech Republic \\ 3Nanobiotechnology, CEITEC-MU, Brno, Czech Republic \\ 4First Department of Internal Medicine, Cardioangiology, St. Anne's University Hospital Brno, Masaryk University, Brno, Czech Republic
}

Correspondence should be addressed to T Jadczyk: tomasz.jadczyk@gmail.com

*(T Jadczyk and G Caluori contributed equally to this work)

\begin{abstract}
Nanotechnology and stem cells are one of the most promising strategies for clinical medicine applications. The article provides an up-to-date view on advances in the field of regenerative and targeted vascular therapies describing a molecular design (propulsion mechanism, composition, target identification) and applications of nanorobots. Stem cell paragraph presents current clinical application of various cell types involved in vascular biology including mesenchymal stem cells, very small embryonic-like stem cells, induced pluripotent stem cells, mononuclear stem cells, amniotic fluid-derived stem cells and endothelial progenitor cells. A possible bridging between the two fields is also envisioned, where bio-inspired, safe, long-lasting nanorobots can fully target the cellular specific cues and even drive vascular process in a timely manner.

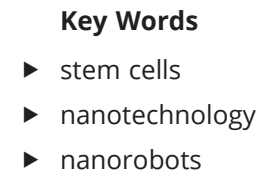

- nanorobots
\end{abstract}

Nanotechnology and stem cells hold a great clinical promise in the field of vascular therapies. Presented review provides an up-to-date summary about advances and challenges associated with these novel treatment strategies.

\section{Nanotechnology systems}

The application of nanotechnology in medicine (nanomedicine) has spawned a galaxy of tools with diagnostic, therapeutic, or ideally theragnostic abilities (1). Nanorobotics, in particular, holds a future yet promising potential to change the panorama of fields like cardiovascular intervention, neurological and cancer treatment (2). The devised technologies, relatively to their aim and complexity, face several translational challenges and attrition (3). Nanoparticles, such as liposomal, polymeric, metallic or their specific combinations are the most investigated and advanced nanotool (in terms of clinical translation). The topic merits an extensive separate description, and the reader is referred to detailed work on the topic (4). We will refer to nanoparticles in the specific contest of load/cargos for nanorobots or specific vascular applications.

Appropriate design of nanorobots design can help diagnosis or accurately deliver payloads, which can be towed or embedded in the structure. Differently from nanoparticles, which are mostly produced and modified in solution-based systems, nanorobotic fabrication also requires the use of technique proper of micro/ nano electromechanical systems. Several definitions are possible for a nanorobotics system, both at the scientific and legislative level (e.g. the classification into drug https://vb.bioscientifica.com

https://doi.org/10.1530/VB-19-0021 (c) 2019 The authors Published by Bioscientifica Ltd

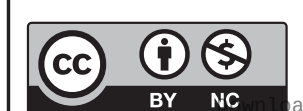

This work is licensed under a Creative Commons Attribution-NonCommercial 4.0 International License.

ded from Bioscientifica.com at 04/26/2023 02:02:55PM 
agent or medical device by the principle of action). A safe definition is an artificial device composed of nanoscale components and up to $10 \mu \mathrm{m}$ in size (5). This description is not standard and that might explain the various and sometimes misused denomination of nanorobots to bionanotechnological devices.

The presently proposed systems can be classified in terms of (i) propulsion, mechanism, (ii) composition, (iii) target identification, (iv) specific application. Propulsion can be autonomous (chemotaxis, bioseparation) or external (magnetic, acoustic, laser) (6). Although intriguing, autonomous propulsion systems (assimilable to molecular motors) are mostly based on the conversion of glucose into hydrogen peroxide (7), raising a concern about the reactive-oxygen species toxicity of such nanotools. The design, safety and motion freedom are greatly facilitated in externally driven nanorobots, usually referred as nanoswimmers (8). These systems can present intrinsic magnetism or embedded magnetic nanoparticles; specific geometry/material-driven torque formation when exposed to stimuli; and material-mediated hydrolyzing properties under UV light (for which the in vivo application is debatable) (6). Mixed propulsion systems have also been investigated (9). Nanorobots can be constituted of purely synthetic materials (10), biomolecules (DNA in the form of origami, aptamers) (11), biological entities (e.g. magnetotactic bacteria) (1), or hybrid cellular (e.g. loaded red blood cells, neutrophils) flagellated nanocomposites $(12,13)$. The target identification employed by these systems may rely on precise localization through focused external driving forces (and this requires precise modeling of the hydrodynamic conditions for different vessel) (14) or on sensed environmental properties and moieties (changes of temperature, $\mathrm{pH}$, osmosis or specific biomarker) (11).

As aforementioned, applications of nanodevices in biological systems cover several and very diversified environments: we will for the scope of this review focus on the application for advancement of vascular intervention. In coronary artery disease, nanotechnological systems have been investigated for its low invasiveness during interventional procedures and drug targeted delivery (15). One instance is use of nano-coated stents for endothelial healing, reendothelialization and anti-restenosis (e.g. with nano-embedded sirolimus, rapamycin, NO-loaded polycaprolactone) $(16,17,18)$ or nanofibrous scaffolds for coronary bypass. The nanofabrication involves mimicking moieties (e.g. dimyristoyl phosphatidylcholine for cholesterol removal (15)) specific targeting (e.g. with local high levels of pravastatins (19) or toward inflammatory monocytes (20)) or clearance prolongation of nanosized drugs (21). The general aim is to provide a long-lasting or permanent implant for resolution of the structural damage in combination with reparative and protective strategies. So far, nanomedicine for vascular therapies is focused mostly on nanoparticles. More specifically to nanorobotic entities, DNA origami and aptamers are extensively studied as antithrombotics and anticoagulants (anti-vWF, factor IX and thrombin) (22).

Another application of nanorobots is the individualization and targeting of microvasculature not accessible with conventional techniques (5). Notable examples include the cerebral vasculature and the network of small tumoral masses that escape resection or conventional therapies. Nanorobots have been indeed proposed to spot brain aneurysm detection (23) and to repair small vessel via Von Willebrand factor (vWF) sensing (24). These systems would greatly aid the interventions on non-navigable or poorly visualizable vasculature. Bacterial systems like non-pathogenic Escherichia coli have been proven to respond by chemotaxis to concentration of VEGF, a well-known angiogenic cytokine (25), pointing at the potential applications of natural molecular machinery and chemosensors. On the theragnostic side, DNA nanorobots targeting nucleolin-expression tumoral endothelium has been tested in vivo, aiming at the starvation of solid tumors by clotting of feeding microvasculature (26). Appropriately designed robots in terms of low toxicity (multiple doses) and retainment can in principle target or drive small tumors at precise checkpoints, making them more sensitive to drugs or conventional therapies.

\section{Stem cells}

Vascular homeostasis depends on endothelium integrity and complex interaction between endothelial cells (ECs), vascular smooth muscle cells, and extracellular matrix (27). Additionally, vascular stem and progenitor cells have been identified in all three layers of the vessel wall (most abundantly in the adventitia) (28).

Recent studies described the effects of heterogeneous cell populations in vascular systems through several mechanisms (paracrine modulation, proliferation, transdifferentiation). This paragraph describes various types of stem cells focusing on current clinical application.

Currently, mesenchymal stem cells (MSCs) are considered as the most promising cell type with a wide range of potential therapeutic applications. MCSs are

This work is licensed under a Creative Commons Attribution-NonCommercial 4.0 International License. 
present in multiple organs (29) throughout human body including adipose tissue (adipose-derived stromal/stem cells, ASCs) and umbilical cord, which provides an easily accessible and expandable source of cells for clinical use (30, 31). Furthermore, MSCs possess particular characteristics: (i) strong angiogenic and paracrine potential, (ii) ability to differentiate to vascular cells contributing to angio- and arteriogenesis (32), (iii) favorable immunogenic profile opening potential for allogenic source (33). Laboratory findings and animal models (34) were confirmed in early phase clinical trials, where autologous ASCs have been showed to provide beneficial clinical effects in patients with critical limb ischemia (35). Moreover, recent myocardial infarction (MI) studies confirmed a safety profile of transendocardial (36) and intracoronary (37) application of allogenic MSCs, which resulted in increased left ventricle ejection fraction (LVEF) and stroke volume. Similarly, meta-analysis including 12 studies showed MSCs to be safe in patients with ischemic heart failure (38).

Other supportive cell candidates can be found in selected but more restricted pools. Amniotic fluid stem cells (AFCS) showed in preclinical studies the possibility of differentiating into vascular cell lineages (39). Moreover, an ongoing clinical trial (NCT03899298, https://clinicaltrials.gov) evaluates safety and efficacy of AFSCs and umbilical cord stem cells for treatment of a broad spectrum of diseases including neurologic, cardiac and pulmonary conditions. Mononuclear cells (MNCs) represent heterogenic population of stem/ progenitor cells including hematopoietic stem cells, endothelial progenitor cells (EPCs) and MSCs. Despite the wide application of MNCs in clinical trials for nonhematopoietic tissue regeneration, the recent metaanalyses showed that MNCs do not improve outcomes in patients with peripheral artery disease $(40,41,42)$ and acute MI (43). Finally, very small embryonic-like stem cells (VSELs) are small-sized cells $(\approx 5-7 \mu \mathrm{m}$ in humans) present in adult tissues with an ability to differentiate into three germ lineages in vitro (including endothelial progenitor) without manipulation with DNA vectors $(44,45)$. Moreover, mobilization of VSELs was reported in humans after MI. Nevertheless, it must be noted that VSELs are a rare cell type; thus, sufficient expansion must be obtained for clinical application (44).

A separate outlook is due when considering differentiation-mediated cell therapy, by using humaninduced pluripotent stem cells (hiPSCs). These hold a great promise for regenerative medicine (ability to differentiate into $\approx 200$ cell types) (45), but present many challenges to overcome prior to clinical step. hiPSCs can be derived from patient-specific somatic cells (i.e. fibroblast), and they can be differentiated into ECs (46), which express angiogenic and reendothelialization potential upon exposure to shear stress $(46,47)$.

Despite promising results in preclinical studies (48), the main limitations for human application include hiPSCs tumorigenicity (49), further transdifferentiation into mature cell type, genomic instability, and risk of mitochondrial mutations (45). To circumvent safety challenges, the novel approaches are incorporated to eliminate the risk of genomic modifications via miRNAs, recombinant proteins and small molecules (50, 51). Presented strategies have a chance to unlock tremendous clinical potential of iPSCs.

A second cell-based approach to vascular therapy can be directly related to resident and circulating EPCs, which do not require passing through differentiation processes. In the light of ongoing scientific debate (52), EPCs of hematopoietic origin are most commonly defined by CD133+/CD34+/vascular endothelial growth factor receptor 2 (VEGFR2+) surface markers (53), while EPCs from non-hematopoietic tissues (adipose tissue, placenta) express various types of antigens (54). Interestingly, endothelial colony-forming cells (ECFCs), a subtype of peripheral blood (PB) EPCs, originate from vessel wall $(55,56)$. Supporting endogenous resident ECs in replacing damaged endothelium, EPCs might be involved in endothelial repair process by paracrine effect (57) or contribute to new vessel formation (58) with the presence of late-stage endothelial markers (59). Furthermore, crosstalk between ECs and EPCs is orchestrated by chemoattractant gradient of growth factors, chemokines, and cytokines (60). Despite encouraging experimental and preclinical therapeutic evidence of EPCs role (61), only modest benefits were found at the clinical level for treatment of MI (+3.15\% LVEF) (62), critical limb ischemia, refractory angina, and chronic myocardial ischemia (63). Moreover, EPCs expressing bone antigens are found to be involved in arterial wall stiffening and calcification (64, $65)$.

\section{Conclusions}

Drawing a final conclusion about the application of nanotechnology and heterologous stem cell pools in human vascular diseases (summarized on Fig. 1) is currently still challenging due to (i) the large heterogeneity of device designs and broad application scopes; 


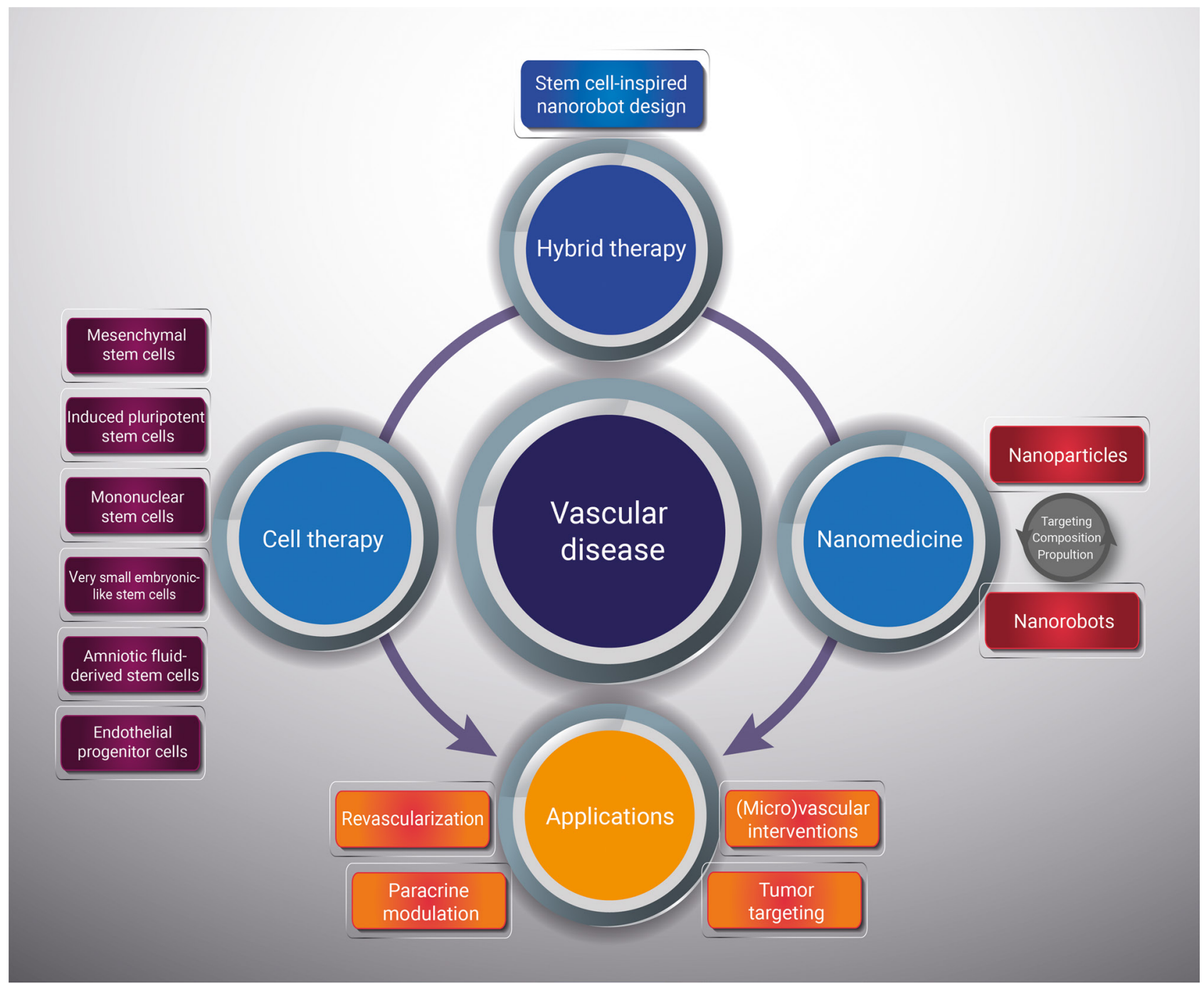

Figure 1

The scope of nanotechnology and stem cell applications in human vascular diseases.

(ii) incomplete cell characterization and administration protocols. The limited follow-up in preclinical and clinical trials leaves open questions common to the two fields, most importantly the grade of systemic biological effect (i.e. oxidative effects of autonomous nanorobots, uncontrolled differentiation cues for stem cells, and organspecific retention in presence of comorbidities) coming from the exogenous material. Non-invasive assisted imaging modalities of nanorobots are fundamental for the long-term monitoring of the therapy, on the one hand. A failsafe quenching mode (e.g. transient supraphysiological temperature degradation) would be also a useful design feature to avoid overtreatment, on the other. Nevertheless, the promised benefits for the two approaches justify further investigation, with a possible envisioned bridging between them. It is not far-fetched, looking at the state of the art, to imagine highly selective piloted DNAsynthetic nanorobots specifically engineered to recognize paracrine stem/progenitor cells exosome. This could allow precise imaging of the interested area and topical deliver therapeutic cargo (e.g. drugs or differentiative cytokines), possibly in a way that will disable the nanorobot and allow its wasting. A tandem work between nanorobotics design and fate/role of vascular stem cells could boost the efficacy and translation of regenerative and targeted vascular therapies.

\section{Declaration of interest}

The authors declare that there is no conflict of interest that could be perceived as prejudicing the impartiality of this review. 


\section{Funding}

This work was supported by (1) Ministry of Education Youth and Sport of Czech Republic (Grant \# ICRC LQ1605), Z S; (2) National Centre for Research and Development (STRATEGMED 2/269415/11/NCBR/2015, STRATEGMED2/265761/10/NCBR/2015, Horizon 2020 SCIENCE, Grant Agreement No 643478), W W.

\section{Author contribution statement}

T J and G C were responsible for article design, literature collection, and drafting of the manuscript. Z S and W W secured funding, critically revised the text and approved the finalized version.

\section{References}

1 Jadczyk T, Bryndza Tfaily E, Mishra S, Jedrzejek M, Boloz M, Padmanabhan P, Wojakowski W, Starek Z, Martel S \& Gulyas B. Innovative Diagnostics and Treatment: Nanorobotics and Stem Cells. Springer Briefs in Applied Science and Technology 2017. Singapore: Springer Singapore. (https://doi.org/10.1007/978-981-10-4527-1)

2 Wamala I, Roche ET \& Pigula FA. The use of soft robotics in cardiovascular therapy. Expert Review of Cardiovascular Therapy 2017 15 767-774. (https://doi.org/10.1080/14779072.2017.1366313)

3 Paliwal R, Babu RJ \& Palakurthi S. Nanomedicine scale-up technologies: feasibilities and challenges. AAPS PharmSciTech 201415 1527-1534. (https://doi.org/10.1208/s12249-014-0177-9)

4 Bobo D, Robinson KJ, Islam J, Thurecht KJ \& Corrie SR. Nanoparticlebased medicines: a review of FDA-approved materials and clinical trials to date. Pharmaceutical Research 201633 2373-2387. (https:// doi.org/10.1007/s11095-016-1958-5)

5 Martel S. Swimming microorganisms acting as nanorobots versus artificial nanorobotic agents: a perspective view from an historical retrospective on the future of medical nanorobotics in the largest known three-dimensional biomicrofluidic networks. Biomicrofluidics 201610 021301. (https://doi.org/10.1063/1.4945734)

6 Sokolov IL, Cherkasov VR, Tregubov AA, Buiucli SR \& Nikitin MP. Smart materials on the way to theranostic nanorobots: molecular machines and nanomotors, advanced biosensors, and intelligent vehicles for drug delivery. Biochimica et Biophysica Acta. General Subjects 20171861 1530-1544. (https://doi.org/10.1016/j.bbagen.2017.01.027)

7 Kumar A, Takatsuki H, Choi CK, Ayusman Sen A \& Eric Blough E. Glucose driven catalytic nanomotor to create motion at micro scale. Journal of Biotech Research 20135 35-39.

8 Zhao G, Viehrig M \& Pumera M. Challenges of the movement of catalytic micromotors in blood. Lab On A Chip 201313 1930-1936. (https://doi.org/10.1039/c3lc41423j)

9 Beladi-Mousavi SM, Khezri B, Krejcova L, Heger Z, Sofer Z, Fisher AC \& Pumera M. Recoverable bismuth-based microrobots: capture, transport, and on-demand release of heavy metals and an anticancer drug in confined spaces. ACS Applied Materials \& Interfaces 201911 13359-13369. (https://doi.org/10.1021/acsami.8b19408)

10 Khezri B \& Pumera M. Metal-organic frameworks based nano/ micro/millimeter-sized self-propelled autonomous machines. Advanced Materials 201931 e1806530. (https://doi.org/10.1002/ adma.201806530)

11 Singh HR, Kopperger E \& Simmel FC. A DNA nanorobot uprises against cancer. Trends in Molecular Medicine 201824 591-593. (https://doi.org/10.1016/j.molmed.2018.05.001)

12 Ali J, Cheang UK, Martindale JD, Jabbarzadeh M, Fu HC \& Jun Kim M. Bacteria-inspired nanorobots with flagellar polymorphic transformations and bundling. Scientific Reports 2017714098. (https://doi.org/10.1038/s41598-017-14457-y)

13 Medina-Sanchez M, Xu H \& Schmidt OG. Micro- and nano-motors: the new generation of drug carriers. Therapeutic Delivery 20189 303-316. (https://doi.org/10.4155/tde-2017-0113)

14 Arcese L, Fruchard M \& Ferreira A. Endovascular magnetically guided robots: navigation modeling and optimization. IEEE Transactions on Bio-Medical Engineering 201259 977-987. (https://doi.org/10.1109/ TBME.2011.2181508)

15 Kandaswamy E \& Zuo L. Recent advances in treatment of coronary artery disease: role of science and technology. International Journal of Molecular Sciences 2018 19. (https://doi.org/10.3390/ijms19020424)

16 Tsukie N, Nakano K, Matoba T, Masuda S, Iwata E, Miyagawa M, Zhao G, Meng W, Kishimoto J, Sunagawa K, et al. Pitavastatinincorporated nanoparticle-eluting stents attenuate in-stent stenosis without delayed endothelial healing effects in a porcine coronary artery model. Journal of Atherosclerosis \& Thrombosis 201320 32-45. (https://doi.org/10.5551/jat.13862)

17 Lu J, Liong M, Li Z, Zink JI \& Tamanoi F. Biocompatibility, biodistribution, and drug-delivery efficiency of mesoporous silica nanoparticles for cancer therapy in animals. Small 20106 1794-1805. (https://doi.org/10.1002/smll.201000538)

18 Acharya G, Lee CH \& Lee Y. Optimization of cardiovascular stent against restenosis: factorial design-based statistical analysis of polymer coating conditions. PLOS ONE 20127 e43100. (https://doi. org/10.1371/journal.pone.0043100)

19 Broz P, Ben-Haim N, Grzelakowski M, Marsch S, Meier W \& Hunziker P. Inhibition of macrophage phagocytotic activity by a receptor-targeted polymer vesicle-based drug delivery formulation of pravastatin. Journal of Cardiovascular Pharmacology 200851 246-252. (https://doi.org/10.1097/FJC.0b013e3181624aed)

20 Leuschner F, Dutta P, Gorbatov R, Novobrantseva TI, Donahoe JS, Courties G, Lee KM, Kim JI, Markmann JF, Marinelli B, et al. Therapeutic siRNA silencing in inflammatory monocytes in mice. Nature Biotechnology 201129 1005-1010. (https://doi.org/10.1038/ nbt.1989)

21 Rhee JW \& Wu JC. Advances in nanotechnology for the management of coronary artery disease. Trends in Cardiovascular Medicine 201323 39-45. (https://doi.org/10.1016/j.tcm.2012.08.009)

22 Mittal R, Jhaveri VM, McMurry HS, Kay SS, Sutherland KJ, Nicole L, Mittal J \& Jayant RD. Recent treatment modalities for cardiovascular diseases with a focus on stem cells, aptamers, exosomes and nanomedicine. Artificial Cells, Nanomedicine, and Biotechnology 2018 46 831-840. (https://doi.org/10.1080/21691401.2018.1436555)

23 Cavalcanti A, Shirinzadeh B, Fukuda T \& Ikeda S. Nanorobot for brain aneurysm. The International Journal of Robotics Research 200928 558-570. (https://doi.org/10.1177/0278364908097586)

24 Trihirun S, Achalakul T \& Kaewkamnerdpong B. Modeling nanorobot control for blood vessel repair: a non-Newtonian blood model. In The 6th 2013 Biomedical Engineering International Conference 2013, Amphur Muang, Thailand.

25 Al-Fandi M, Alshraiedeh N, Oweis R, Alshdaifat H, Al-Mahaseneh O, Al-Tall K \& Alawneh R 2017 Erratum: Al-Fandi M, Alshraiedeh N, Oweis R, Alshdaifat H, Al-Mahaseneh O, Al-Tall K \& Alawneh R. Novel selective detection method of tumor angiogenesis factors using living nano-robots. Sensors (Basel, Switzerland) 2017171580. (https://doi.org/10.3390/s17071580)

26 Li S, Jiang Q, Liu S, Zhang Y, Tian Y, Song C, Wang J, Zou Y, Anderson GJ, Han JY, et al. A DNA nanorobot functions as a cancer therapeutic in response to a molecular trigger in vivo. Nature Biotechnology 201836 258-264. (https://doi.org/10.1038/nbt.4071)

27 Chandra P \& Atala A. Engineering blood vessels and vascularized tissues: technology trends and potential clinical applications. Clinical Science 2019133 1115-1135. (https://doi.org/10.1042/ CS20180155) https://vb.bioscientifica.com

https://doi.org/10.1530/VB-19-0021 (c) 2019 The authors Published by Bioscientifica Ltd

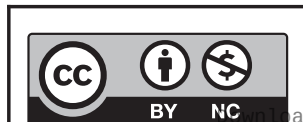

This work is licensed under a Creative Commons Attribution-NonCommercial 4.0 International License. led from Bioscientifica com at $04 / 26 / 2023 \quad 02: 02: 55 \mathrm{PM}$ 
28 Wang D, Li LK, Dai T, Wang A \& Li S. Adult stem cells in vascular remodeling. Theranostics $2018 \mathbf{8} 815-829$. (https://doi.org/10.7150/ thno.19577)

29 Fitzsimmons REB, Mazurek MS, Soos A \& Simmons CA. Mesenchymal stromal/stem cells in regenerative medicine and tissue engineering. Stem Cells International 20182018 8031718. (https:// doi.org/10.1155/2018/8031718)

30 Karantalis V \& Hare JM. Use of mesenchymal stem cells for therapy of cardiac disease. Circulation Research 2015116 1413-1430. (https:// doi.org/10.1161/CIRCRESAHA.116.303614)

31 Musialek P, Mazurek A, Jarocha D, Tekieli L, Szot W, Kostkiewicz M, Banys RP, Urbanczyk M, Kadzielski A, Trystula M, et al. Myocardial regeneration strategy using Wharton's jelly mesenchymal stem cells as an off-the-shelf 'unlimited' therapeutic agent: results from the acute myocardial infarction first-in-Man Study. Postepy $w$ Kardiologii Interwencyjej = Advances in Interventional Cardiology 201511 100-107. (https://doi.org/10.5114/pwki.2015.52282)

32 Wingate K, Floren M, Tan Y, Tseng PO \& Tan W. Synergism of matrix stiffness and vascular endothelial growth factor on mesenchymal stem cells for vascular endothelial regeneration. Tissue Engineering. Part A 201420 2503-2512. (https://doi.org/10.1089/ten. TEA.2013.0249)

33 Machado Cde V, Telles PD \& Nascimento IL. Immunological characteristics of mesenchymal stem cells. Revista Brasileira de Hematologia e Hemoterapia 201335 62-67. (https://doi. org/10.5581/1516-8484.20130017)

34 Iwase T, Nagaya N, Fujii T, Itoh T, Murakami S, Matsumoto T, Kangawa K \& Kitamura S. Comparison of angiogenic potency between mesenchymal stem cells and mononuclear cells in a rat model of hindlimb ischemia. Cardiovascular Research 200566 543-551. (https://doi.org/10.1016/j.cardiores.2005.02.006)

35 Bura A, Planat-Benard V, Bourin P, Silvestre JS, Gross F, Grolleau JL, Saint-Lebese B, Peyrafitte JA, Fleury S, Gadelorge M, et al. Phase I trial: the use of autologous cultured adipose-derived stroma/ stem cells to treat patients with non-revascularizable critical limb ischemia. Cytotherapy 201416 245-257. (https://doi.org/10.1016/j. jcyt.2013.11.011)

36 Perin EC, Borow KM, Silva GV, DeMaria AN, Marroquin OC, Huang PP, Traverse JH, Krum H, Skerrett D, Zheng Y, et al. A phase II dose-escalation study of allogeneic mesenchymal precursor cells in patients with ischemic or nonischemic heart failure. Circulation Research 2015117 576-584. (https://doi.org/10.1161/ CIRCRESAHA.115.306332)

37 Penn MS, Ellis S, Gandhi S, Greenbaum A, Hodes Z, Mendelsohn FO, Strasser D, Ting AE \& Sherman W. Adventitial delivery of an allogeneic bone marrow-derived adherent stem cell in acute myocardial infarction: phase I clinical study. Circulation Research 2012 110 304-311. (https://doi.org/10.1161/CIRCRESAHA.111.253427)

38 Lalu MM, Mazzarello S, Zlepnig J, Dong YYR, Montroy J, McIntyre L, Devereaux PJ, Stewart DJ, David Mazer C, Barron CC, et al. Safety and efficacy of adult stem cell therapy for acute myocardial infarction and ischemic heart failure (SafeCell heart): a systematic review and meta-analysis. Stem Cells Translational Medicine 20187 857-866. (https://doi.org/10.1002/sctm.18-0120)

39 Maraldi T, Riccio M, Pisciotta A, Zavatti M, Carnevale G, Beretti F, La Sala GB, Motta A \& De Pol A. Human amniotic fluid-derived and dental pulp-derived stem cells seeded into collagen scaffold repair critical-size bone defects promoting vascularization. Stem Cell Research \& Therapy 20134 53. (https://doi.org/10.1186/scrt203)

40 Rigato M, Monami M \& Fadini GP. Autologous cell therapy for peripheral arterial disease: systematic review and meta-analysis of randomized, nonrandomized, and noncontrolled studies. Circulation Research 2017120 1326-1340. (https://doi.org/10.1161/ CIRCRESAHA.116.309045)

41 Qadura M, Terenzi DC, Verma S, Al-Omran M \& Hess DA. Concise review: cell therapy for critical limb ischemia: an integrated review of preclinical and clinical studies. Stem Cells 201836 161-171. (https:// doi.org/10.1002/stem.2751)

42 Bartunek J \& Wojakowski W. Intracoronary autologous bone marrow cell transfer after acute myocardial infarction: abort and refocus. European Heart Journal 201738 2944-2947. (https://doi.org/10.1093/ eurheartj/ehx300)

43 Gyongyosi M, Wojakowski W, Navarese EP, Moye LÀ \& ACCRUE Investigators. Meta-analyses of human cell-based cardiac regeneration therapies: controversies in meta-analyses results on cardiac cell-based regenerative studies. Circulation Research 2016118 1254-1263. (https://doi.org/10.1161/CIRCRESAHA.115.307347)

44 Ratajczak MZ, Ratajczak J \& Kucia M. Very small embryonic-like stem cells (VSELs). Circulation Research 2019124 208-210. (https://doi. org/10.1161/CIRCRESAHA.118.314287)

45 Bhartiya D. Clinical translation of stem cells for regenerative medicine. Circulation Research 2019124 840-842. (https://doi. org/10.1161/CIRCRESAHA.118.313823)

46 Sivarapatna A, Ghaedi M, Le AV, Mendez JJ, Qyang Y \& Niklason LE. Arterial specification of endothelial cells derived from human induced pluripotent stem cells in a biomimetic flow bioreactor. Biomaterials 201553 621-633. (https://doi.org/10.1016/j. biomaterials.2015.02.121)

47 Suzuki H, Shibata R, Kito T, Yamamoto T, Ishii M, Nishio N, Ito S, Isobe $\mathrm{K} \&$ Murohara T. Comparative angiogenic activities of induced pluripotent stem cells derived from young and old mice. PLOS ONE 20127 e39562. (https://doi.org/10.1371/journal.pone.0039562)

48 Gu M, Nguyen PK, Lee AS, Xu D, Hu S, Plews JR, Han L, Huber BC, Lee WH, Gong Y, et al. Microfluidic single-cell analysis shows that porcine induced pluripotent stem cell-derived endothelial cells improve myocardial function by paracrine activation. Circulation Research 2012111 882-893. (https://doi.org/10.1161/ CIRCRESAHA.112.269001)

49 Yamanaka S. Induced pluripotent stem cells: past, present, and future. Cell Stem Cell 201210 678-684. (https://doi.org/10.1016/j. stem.2012.05.005)

50 Grath A \& Dai G. Direct cell reprogramming for tissue engineering and regenerative medicine. Journal of Biological Engineering 201913 14. (https://doi.org/10.1186/s13036-019-0144-9)

51 Borgohain MP, Haridhasapavalan KK, Dey C, Adhikari P \& Thummer RP. An insight into DNA-free reprogramming approaches to generate integration-free induced pluripotent stem cells for prospective biomedical applications. Stem Cell Reviews and Reports 201915 286-313. (https://doi.org/10.1007/s12015-018-9861-6)

52 Medina RJ, Barber CL, Sabatier F, Dignat-George F, Melero-Martin JM, Khosrotehrani K, Ohneda O, Randi AM, Chan JKY, Yamaguchi T, et al. Endothelial progenitors: a consensus statement on nomenclature. Stem Cells Translational Medicine 20176 1316-1320. (https://doi.org/10.1002/sctm.16-0360)

53 Peichev M, Naiyer AJ, Pereira D, Zhu Z, Lane WJ, Williams M, Oz MC, Hicklin DJ, Witte L, Moore MA, et al. Expression of VEGFR-2 and AC133 by circulating human CD34(+) cells identifies a population of functional endothelial precursors. Blood 200095 952-958

54 Chong MS, Ng WK \& Chan JK. Concise review: endothelial progenitor cells in regenerative medicine: applications and challenges. Stem Cells Translational Medicine 20165 530-538. (https:// doi.org/10.5966/sctm.2015-0227)

55 Ingram DA, Mead LE, Tanaka H, Meade V, Fenoglio A, Mortell K, Pollok K, Ferkowicz MJ, Gilley D \& Yoder MC. Identification of a novel hierarchy of endothelial progenitor cells using human peripheral and umbilical cord blood. Blood $20041042752-2760$. (https://doi.org/10.1182/blood-2004-04-1396)

56 Melero-Martin JM, Khan ZA, Picard A, Wu X, Paruchuri S \& Bischoff J. In vivo vasculogenic potential of human blood-derived endothelial progenitor cells. Blood 2007109 4761-4768. (https://doi. org/10.1182/blood-2006-12-062471) 
57 Zhang M, Malik AB \& Rehman J. Endothelial progenitor cells and vascular repair. Current Opinion in Hematology 201421 224-228. (https://doi.org/10.1097/MOH.0000000000000041)

58 Li DW, Liu ZQ, Wei J, Liu Y \& Hu LS. Contribution of endothelial progenitor cells to neovascularization (Review). International Journal of Molecular Medicine 201230 1000-1006. (https://doi.org/10.3892/ ijmm.2012.1108)

59 Ambasta RK, Kohli H \& Kumar P. Multiple therapeutic effect of endothelial progenitor cell regulated by drugs in diabetes and diabetes related disorder. Journal of Translational Medicine 201715 185. (https://doi.org/10.1186/s12967-017-1280-y)

60 Wojakowski W, Landmesser U, Bachowski R, Jadczyk T \& Tendera M. Mobilization of stem and progenitor cells in cardiovascular diseases. Leukemia 201226 23-33. (https://doi.org/10.1038/leu.2011.184)

61 Kalka C, Masuda H, Takahashi T, Kalka-Moll WM, Silver M, Kearney M, Li T, Isner JM \& Asahara T. Transplantation of ex vivo expanded endothelial progenitor cells for therapeutic neovascularization. Proceedings of the National Academy of Sciences of the United States of America 200097 3422-3427. (https://doi. org/10.1073/pnas.070046397)
62 Li R, Li XM \& Chen JR. Clinical efficacy and safety of autologous stem cell transplantation for patients with ST-segment elevation myocardial infarction. Therapeutics \& Clinical Risk Management 2016 12 1171-1189. (https://doi.org/10.2147/TCRM.S107199)

63 Hou Y \& Li C. Stem/progenitor cells and their therapeutic application in cardiovascular disease. Frontiers in Cell \& Developmental Biology 20186 139. (https://doi.org/10.3389/ fcell.2018.00139)

64 Pirro M, Manfredelli MR, Schillaci G, Helou RS, Bagaglia F, Melis F, Scalera GB, Scarponi AM, Gentile E \& Mannarino E. Association between circulating osteoblast progenitor cells and aortic calcifications in women with postmenopausal osteoporosis. Nutrition, Metabolism, and Cardiovascular Diseases 201323 466-472. (https:// doi.org/10.1016/j.numecd.2011.08.006)

65 Pirro M, Schillaci G, Mannarino MR, Scarponi AM, Manfredelli MR, Callarelli L, Leli C, Fabbriciani G, Helou RS, Bagaglia F, et al. Circulating immature osteoprogenitor cells and arterial stiffening in postmenopausal osteoporosis. Nutrition, Metabolism, and Cardiovascular Diseases 201121 636-642. (https://doi.org/10.1016/j. numecd.2010.01.015)

Received in final form 19 September 2019

Accepted 24 September 2019

Accepted Preprint published online 24 September 2019 (c) 2019 The authors Published by Bioscientifica Ltd

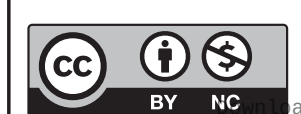

This work is licensed under a Creative Commons Attribution-NonCommercial 4.0 International

License.
ded from Bioscientifica.com at $04 / 26 / 2023$ 02:02:55PM 